\title{
Wintertime storage of water in buried supraglacial lakes across the Greenland Ice Sheet
}

\author{
L. S. Koenig ${ }^{1, a}$, D. J. Lampkin ${ }^{2}$, L. N. Montgomery ${ }^{2}$, S. L. Hamilton ${ }^{3}$, J. B. Turrin ${ }^{4}$, C. A. Joseph ${ }^{2}$, S. E. Moutsafa ${ }^{5}$,

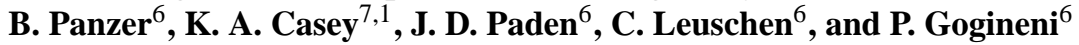 \\ ${ }^{1}$ Cryospheric Sciences Laboratory, NASA Goddard Space Flight Center, Greenbelt, MD, USA \\ ${ }^{2}$ Department of Atmospheric and Oceanic Sciences, University of Maryland, College Park, MD, USA \\ ${ }^{3}$ Bowdoin College, Brunswick, ME, USA \\ ${ }^{4}$ Department of Geography, University of Utah, Salt Lake City, UT, USA \\ ${ }^{5}$ Department of Geography, Rutgers, The State University of New Jersey, Piscataway, NJ, USA \\ ${ }^{6}$ Center for Remote Sensing of Ice Sheets, University of Kansas, Lawrence, KS, USA \\ ${ }^{7}$ Earth System Science Interdisciplinary Center, University of Maryland, College Park, MD, USA \\ ${ }^{a}$ now at: National Snow and Ice Data Center, University of Colorado, Boulder, CO, USA
}

Correspondence to: L. S. Koenig (lora.koenig@ colorado.edu)

Received: 26 June 2014 - Published in The Cryosphere Discuss.: 18 July 2014

Revised: 13 May 2015 - Accepted: 16 June 2015 - Published: 13 July 2015

\begin{abstract}
Increased surface melt over the Greenland Ice Sheet (GrIS) is now estimated to account for half or more of the ice sheet's total mass loss. Here, we show that some meltwater is stored, over winter, in buried supraglacial lakes. We use airborne radar from Operation IceBridge between 2009 and 2012 to detect buried supraglacial lakes, and we find that they were distributed extensively around the GrIS margin through that period. Buried supraglacial lakes can persist through multiple winters and are, on average, $\sim 1.9+0.2 \mathrm{~m}$ below the surface. Most buried supraglacial lakes exist with no surface expression of their occurrence in visible imagery. The few buried supraglacial lakes that do exhibit surface expression have a unique visible signature associated with a darker blue color where subsurface water is located. The volume of retained water in the buried supraglacial lakes is likely insignificant compared to the total mass loss from the GrIS, but the water may have important implications locally for the development of the englacial hydrologic system and ice temperatures. Buried supraglacial lakes represent a small but year-round source of meltwater in the GrIS hydrologic system.
\end{abstract}

\section{Introduction}

Annual mass loss from the Greenland Ice Sheet (GrIS) has increased substantially, quadrupling in the last two decades (Shepherd et al., 2012). Warming Arctic temperatures (e.g., Comiso, 2003; Hall et al., 2013) and a decrease in ice-sheet albedo (e.g., Angelen et al., 2014; Box et al., 2012; Tedesco et al., 2011) have increased surface melt, which now accounts for half or more of the total mass loss, outpacing ice dynamics in recent years (van den Broeke et al., 2009; Enderlin et al., 2014; Khan et al., 2014). Even with the increasing GrIS surface melt, highlighted by a record melt and runoff event in 2012 (Nghiem et al., 2012; Hall et al., 2013; Hanna et al., 2014), the meltwater mass fluxing through and retained within the supra-, en- and subglacial hydrologic networks is relatively unquantified, making ice-sheet-wide water budgets difficult to balance (Rennermalm et al., 2013; Forster et al., 2013).

While regional climate models agree relatively well on precipitation amounts across the GrIS ( $\sim 20 \%$ variance), they still have large discrepancies in melt production, refreezing and runoff (38-83\% variance; Vernon et al., 2013). This is due not only to differences in the models but also to insufficient field observations for quantifying meltwater retention, transport and runoff (Rennermalm et al., 2013). Field observations have only recently discovered large amounts of 


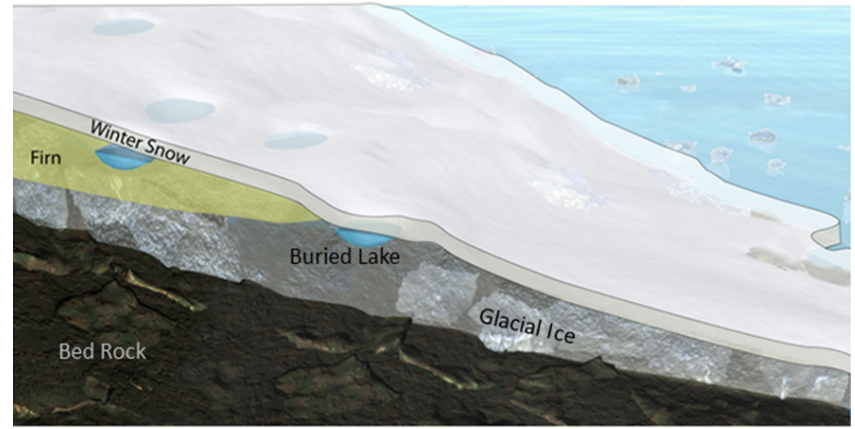

Figure 1. An illustration showing an early spring cross-sectional and perspective view of buried supraglacial lakes (blue), existing under the seasonal snow layer, still filled with water after the winter season.

water retention (Forster et al., 2013; Koenig et al., 2014) and latent heating from refreezing (Harper et al., 2012; Humphrey et al., 2012) on the perimeter of the GrIS, and model improvements to account for the water retention are still in their initial stages (Kuipers Munneke et al., 2014). These recent discoveries punctuate that more observations are needed of the GrIS hydrologic system, especially at and just below the ice-sheet surface, to fully understand meltwater transport and eventual runoff.

This paper presents an initial study and mapping of overwinter surface-melt retention in buried supraglacial lakes (Fig. 1) within the GrIS. We define a "buried supraglacial lake", hereafter for brevity a "buried lake", as water retained through a winter season at shallow depths within the ice sheet that originally formed, during a previous melt season, as a (subaerial) supraglacial lake. Thus, a buried lake is a specific type of supraglacial lake that spans the boundary between the supra- and englacial hydrologic system, exists under lake ice and snow/firn layers in some seasons, and can re-emerge as a supraglacial lake in others. Near-surface, high-resolution radar data, collected during the Arctic spring campaigns of Operation IceBridge (OIB), clearly show water retention in buried lakes through the winter season. In this paper, we use OIB radar data to map the extent and depth of buried lakes across the GrIS. This effort is the first to characterize wintertime meltwater storage in buried lakes over the GrIS and provide an assessment of its impact on the hydrologic system.

\section{Background}

Several researchers have studied supraglacial lakes that are easily distinguishable by visible and radar satellites when they form seasonally in the ablation and percolation zones across the GrIS (Echelmeyer et al., 1991; Box and Ski, 2007; McMillan et al., 2007; Sneed and Hamilton, 2007; Sundal et al., 2009; Lampkin, 2011; Selmes et al., 2011; Tedesco and
Steiner, 2011; Howat et al., 2013). Supraglacial lakes form in local topographic lows formed by bedrock depressions, which are not advected by the ice, and often reform in the same locations (Echelmeyer et al., 1991; Box and Ski, 2007; Selmes et al., 2011). Das et al. (2008) observed the rapid $(<2 \mathrm{~h})$ drainage of a supraglacial lake through fractures, delivering surface meltwater to the bedrock-ice interface, causing local uplift and glacier acceleration. Further studies have expanded the links between supraglacial lakes and waterfilled crevasses and the en- and subglacial hydrologic system, clearly showing that surface meltwater can be routed to the bed of the GrIS, affecting ice dynamics (Zwally et al., 2002; Joughin et al., 2008; Catania et al., 2008; Bartholomew et al., 2011; Palmer et al., 2011; Sundal et al., 2011; Hoffman et al., 2011; Tedstone et al., 2013).

Most studies assume that supraglacial lakes either drain during the summer, through the supraglacial or englacial hydrologic system, or refreeze during the winter. Few studies have investigated the behavior of supraglacial lakes during the winter season. Ohmura et al. (1991) attributed the presence of ice plates they observed on the snow surface at West Lake near Swiss Camp, western Greenland, to the persistence of water late into winter, which formed a frozen ice layer and then drained. Additionally, they detected a deep lake $(\sim 10 \mathrm{~m})$ to the east of Swiss Camp that likely remained water-filled through the winter, and developed lake ice up to $1.5 \mathrm{~m}$ thick, before it drained in spring or early summer. Rennermalm et al. (2013) also reported evidence of water retention somewhere within the GrIS hydrologic system, from peaks in stream discharge that occur in the fall and spring, up to 6 months after surface melt. The buried lakes that we identify and map, using radar data, in this paper represent a hitherto understudied proportion of wintertime storage of water.

\section{Data}

\subsection{Radar data}

To identify and map subsurface water, we use data acquired by the CReSIS (University of Kansas' Center for Remote Sensing of Ice Sheets) ultra-wideband Snow Radar during OIB Arctic campaigns from 2009 through 2012 (Leuschen, 2014). The radar operates over the frequency range from $\sim 2$ to $6.5 \mathrm{GHz}$ where water has a high absorption coefficient resulting in the attenuation of radar waves and a strong reflection of the wave at the ice-water interface due to the large difference between the dielectric constant of ice and water (Fig. 2) (Ulaby et al., 1981). The Snow Radar uses a frequency-modulated continuous-wave (FMCW) design which provides a vertical resolution of $\sim 4 \mathrm{~cm}$ in snow/firn to a depth of tens of meters. Radar backscatter along a transect is often displayed as an echogram (Fig. 2) which provides a visual image of the subsurface returns. For additional details 
on the Snow Radar performance see Panzer et al. (2013) and Rodriguez-Morales et al. (2014).

\subsection{Visible and thermal imagery}

Visible imagery from several imaging platforms is used to support the analysis of buried lakes. OIB Digital Mapping System (DMS) imagery, acquired coincident with Snow Radar data, is used to examine surface features indicative of the presence of subsurface water. Cloud-free Moderate Resolution Imaging Spectroradiometer (MODIS) Rapid Response Arctic subset true-color imagery ( $250 \mathrm{~m}$ resolution) is used to determine whether (subaerial) supraglacial lakes formed previously at the locations of the radar-located buried lakes. Additionally, at a sample lake site, MODIS Land Surface Temperature (LST) data are used to corroborate melt onset and surface thermal conditions, and Landsat Enhanced Thematic Mapper (ETM+) panchromatic imagery, with a resolution of $\sim 15 \mathrm{~m}$, is used to evaluate the summertime evolution of the lake.

DMS acquires imagery in the visible part of the electromagnetic spectrum at a nominal resolution of $10 \mathrm{~cm}$ (at $\sim 500 \mathrm{~m}$ a.g.l., the nominal OIB flight altitude). DMS collects data over three multispectral and panchromatic bands using a 21-megapixel Canon EOS 5D Mark II digital camera. Data are orthorectified and corrected for camera orientation using the Applanix POS AV navigation system. For additional details see Dominguez (2014).

MODIS LST (MOD11A1, version 5.1) swath data at $1 \mathrm{~km}$ resolution are accurate to within $\pm 1{ }^{\circ} \mathrm{C}$ (Wan et al., 2002) for snow and ice surface temperatures between -15 and $0{ }^{\circ} \mathrm{C}$ (Hall et al., 2008). MODIS LSTs acquired over the GrIS, however, can be $\sim 1$ to $3{ }^{\circ} \mathrm{C}$ colder than the actual surface temperatures (Hall et al., 2013; Koenig and Hall, 2010).

\section{Methods}

\subsection{Detection of buried lakes from airborne radar}

All Snow Radar echograms over the GrIS from 2009 to 2012 (e.g., Fig. 2b) were inspected manually for subsurface attenuations of the radar backscatter, which could be attributed to a buried lake. To ensure the radar response was associated with englacial water, and not some other density or dielectric change, all 2011 detections from Snow Radar data were compared to either the Accumulation Radar $(\sim 600-900 \mathrm{MHz})$ or MCoRDS (Multichannel Coherent Radar Depth Sounders) Radar ( 140-260 MHz), flown simultaneously with the Snow Radar on board the OIB aircraft (Fig. 2). Water attenuates across radar frequencies. If at least one additional radar showed attenuated backscatter, the detection remained in the data set. Additionally, all detections were compared to summertime cloud-free MODIS imagery to evaluate whether a subaerial supraglacial lake formed at a given radar-located buried lake's location during a preceding melt

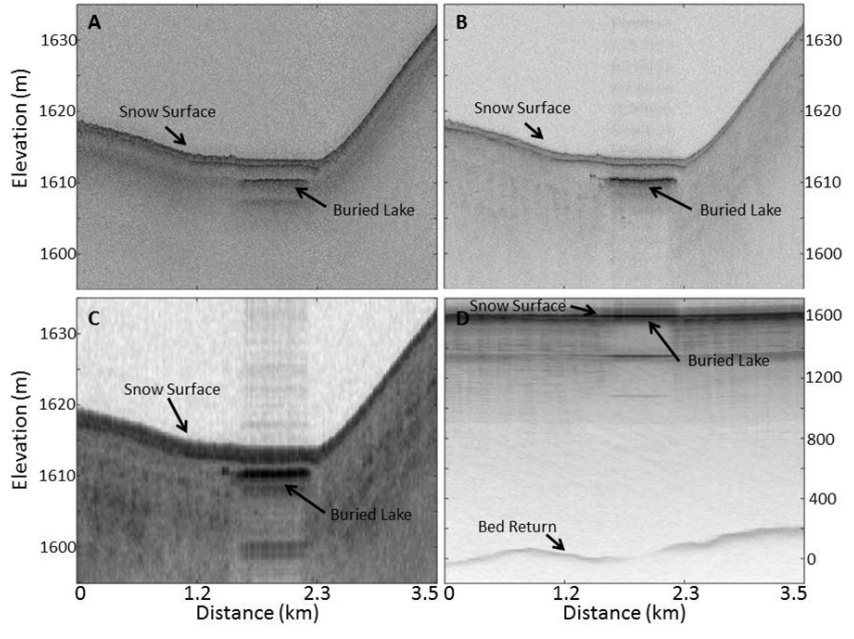

Figure 2. Radar echograms from western Greenland ( $~ 90 \mathrm{~km}$ inland of Jakobshavn's terminus) showing radar signal attenuation at multiple frequencies over a buried lake from the (a) Ku-band Radar ( 13-17 GHz), (b) Snow Radar ( 2-6.5 GHz), (c) Accumulation Radar $(\sim 600-900 \mathrm{MHz})$ and (d) MCoRDS Radar $(\sim 140-$ $260 \mathrm{MHz})$.

season (Fig. 3). The 2011 Snow Radar data were chosen for this initial analysis because it was the first year in which the OIB radar operators discovered the unique return over supraglacial lake regions.

The analysis of the 2011 Snow Radar data led to two characteristic echogram patterns for englacial water retention: buried lakes (e.g., Fig. 2b) and water-filled crevasse fields. The water-filled crevasse fields were not included in the analysis presented here because, though it is likely they contain englacial water, it is also possible that the crevasses themselves, or hoar crystals formed within them, scatter the radar signal in a manner that cannot be distinguished from scatter caused directly by reflections off subsurface water. Additional field verification, beyond the scope of this study, would be needed to interpret radar backscatter over crevassed regions.

The detected buried lakes from 2011 were mapped using approximately each lake's center point and were compared to high-resolution (centimeter-scale) DMS imagery of the GrIS surface coincident with the radar collection (Fig. 4) (Dominguez, 2014). DMS imagery was used to characterize visually the surface roughness, detect crevasses and look for any distinct surface expression of the buried lakes.

Finally, to construct time series of buried lakes, the characteristic buried-lake radar returns (Fig. 2b), determined as we have outlined from the 2011 data, were used to map buried lakes in OIB Snow Radar data from the 2009, 2010 and 2012. Buried lakes that formed within $1 \mathrm{~km}$ of each other from year to year were considered the same feature. This is justified considering Selmes et al. (2011), who reported a median area of $0.56 \mathrm{~km}^{2}$ and a mean area of $0.80 \mathrm{~km}^{2}$ for lakes across the 


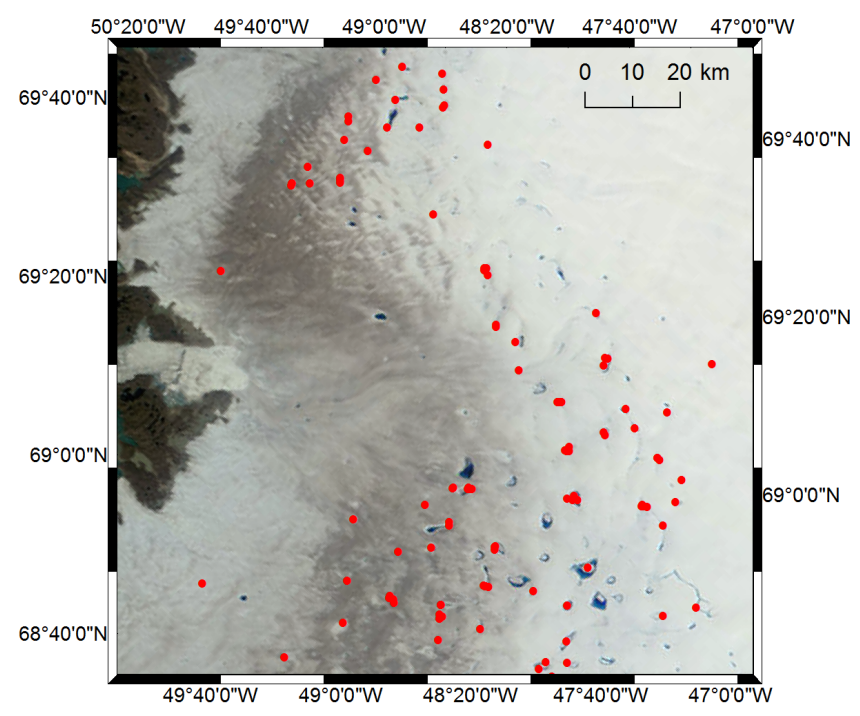

Figure 3. Radar-detected buried lake locations (red dots) overlain on MODIS Rapid Response image from 7 August 2010. Note clear correspondence of radar-detected lake locations with many supraglacial lakes clearly visible in this image; all the buried lakes in the data set were associated with visible supraglacial lakes captured in at least one MODIS image over the analysis period.
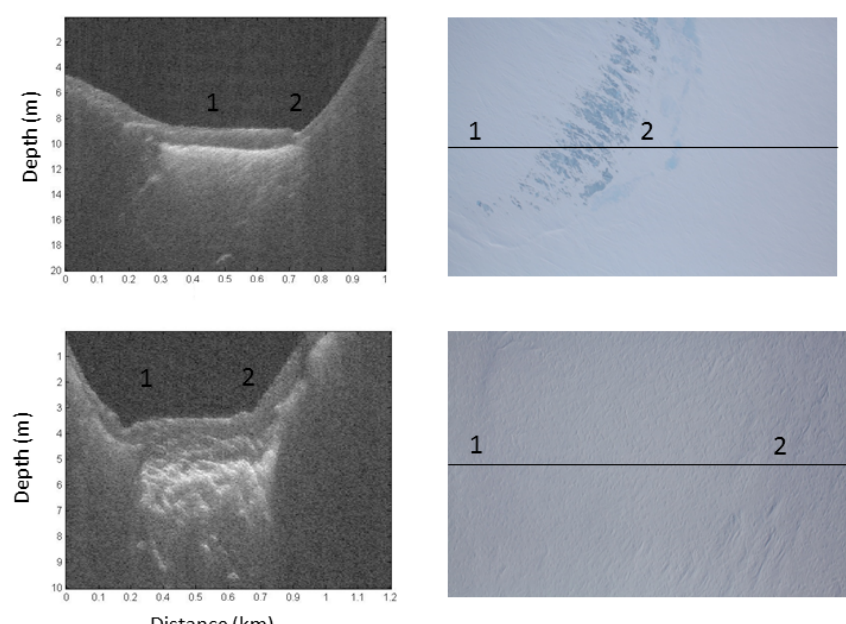

Figure 4. Snow Radar echograms of buried lakes (left) with DMS imagery of the GrIS surface (right) from (top) a rare buried lake in northwest Greenland $(\sim 45 \mathrm{~km}$ inland from the terminus of Steenstrup Glacier) with a surface expression showing darker blue where there is buried liquid water and a more turquoise, lighter blue where the lake is frozen through and from (bottom) a typical buried lake in western Greenland $(\sim 60 \mathrm{~km}$ inland from the terminus of Jakobshavn Isbræ) showing surface sastrugi and no detectable lake surface expression.

GrIS. Because the buried lakes are mapped using an approximate center point, a $1 \mathrm{~km}$ radius is a reasonable distance to be considered the same feature along the changing OIB flight lines.

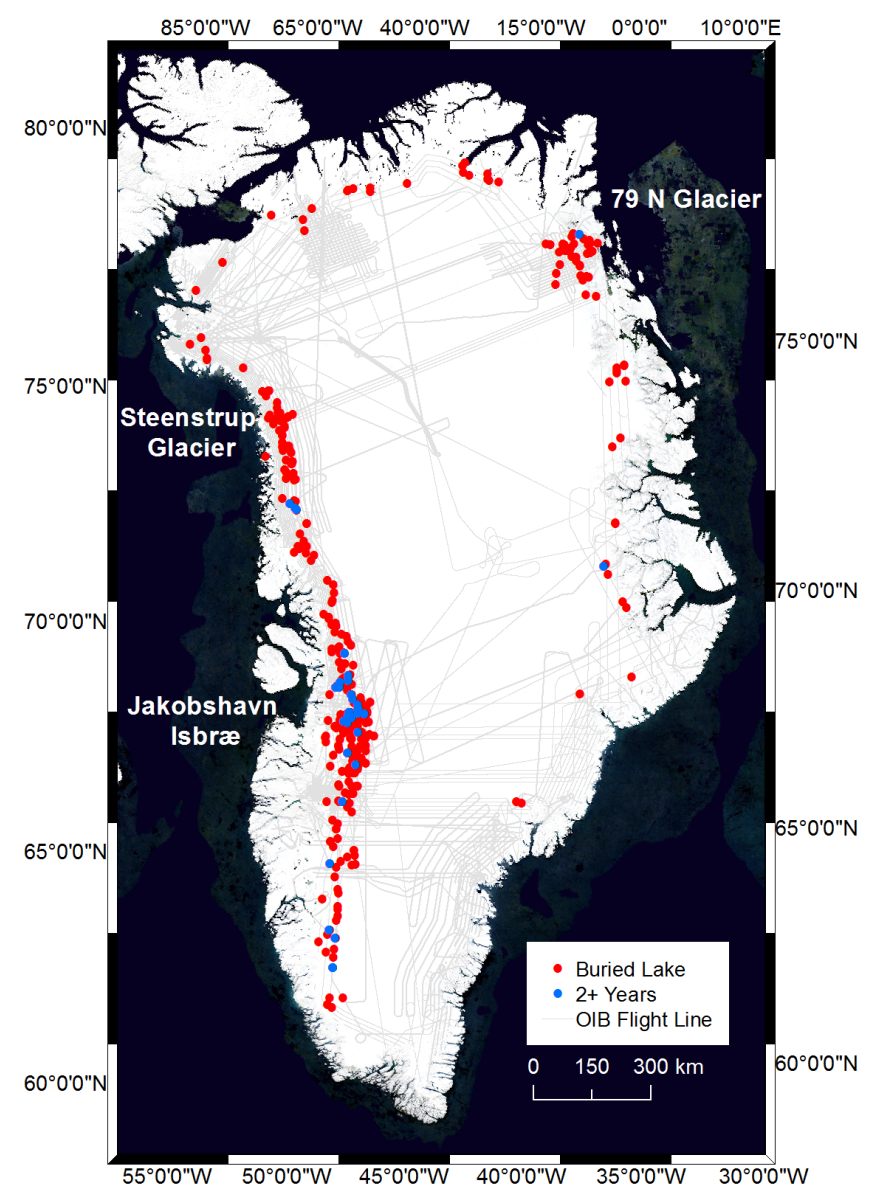

Figure 5. Locations of buried lakes (red circles) and multi-year buried lakes (blue circles) from 2009 to 2012 with OIB flight lines (gray lines).

\subsection{Depth retrieval of the water surface}

The 2009-2012 Snow Radar echograms of the buried lakes were digitized manually to determine the depth from the snow surface to the water surface. If distinguishable in the echogram, as shown in Fig. 2b, both the snow/lake-ice interface and the lake-ice/water interface were digitized. When a snow layer was digitized, a reasonable near-surface snow density of $320 \mathrm{~kg} \mathrm{~m}^{-3}$ (Benson, 1962) was assumed to convert radar travel time to depth using equations developed by Wiesmann and Matzler (1999). When a lake ice layer was digitized or if only the snow surface and the water layer were digitized, the dielectric properties of ice were assumed to convert radar travel time to depth (relative permittivity, $\varepsilon=3.2$; Dowdeswell and Evans, 2004). In the absence of field data providing a stratigraphic density profile, the adoption of ice density values biases the depth measurements to shallower depths. Uncertainties in the depth were estimated by taking the subset of radar echograms where a snow layer was detected and calculating the depth with both the snow 
layer and ice assumptions. The average percent difference defines the uncertainty at $9 \%$ (range of 2 to $24 \%$ ) shallow.

\section{Results}

\subsection{Spatial and temporal distribution of buried lakes}

The wintertime storage of meltwater in buried lakes is extensive around the margin of the GrIS (Fig. 5). All buried lakes identified from 2009 to 2012 were below the $2000 \mathrm{~m}$ contour, with the majority detected between 1000 and $2000 \mathrm{~m}$ on the west coast of the ice sheet (Fig. 5). Table 1 provides the number of buried lakes detected each year, the mean and standard deviation of buried lake elevation, the number of buried lakes below $1000 \mathrm{~m}$ and the number of lakes detected per $1000 \mathrm{~km}$ of OIB flight lines flown below $2000 \mathrm{~m}$. Because OIB is an airborne mission with a changing set of flight lines leading to an inconsistent spatial sampling, and thus regionally biased sampling, these results must be analyzed with caution and in full appreciation of the characteristics of the survey campaigns. Thus, for example, while in Table 1 it appears that more lakes were detected in 2011, there were also more flight lines in 2011 below $2000 \mathrm{~m}$, and many of these were along the west coast.

Clusters of buried lakes are concentrated along the west coast of Greenland and near 79 N Glacier where OIB gridded flight lines are flown repeatedly in multiple years (Fig. 5). It is also in these regions where we detect buried lakes that persist for multiple years (Fig. 5). Again, these multi-year detections must be taken in the context that they are detected in areas with high concentrations of supraglacial lakes where OIB flight lines are repeated in multiple years. It is very likely that other buried lakes are present through multiple winters yet were not detected in more than 1 year due to the limited OIB spatial and repeat sampling. In total, 53 lakes were detected in 2 of the 4 years, and 7 lakes were detected in three of the 4 years (Fig. 5). All lakes detected over three seasons are located on the OIB grid near Jakobshavn Isbræ that is repeated annually.

\subsection{Surface expression of buried lakes and lake evolution}

DMS imagery rarely shows any surface expression of buried lakes. Only at five locations was a unique surface expression found when the buried lake's ice covered surface was exposed. Two examples are shown in Figs. 4 and 6. These figures show a surface expression of the darker blue ice adjacent to a region of lighter-colored ice that corresponds with the transitional zone from water detection (attenuation) to no water detection (penetration) in the radar echograms (Figs. 4 and 6). The darker blue color associated with the retained water can be explained by the vibrational transitions as well as the higher density and temperature of water molecules in the buried lake resulting in a stronger hydrogen-oxygen

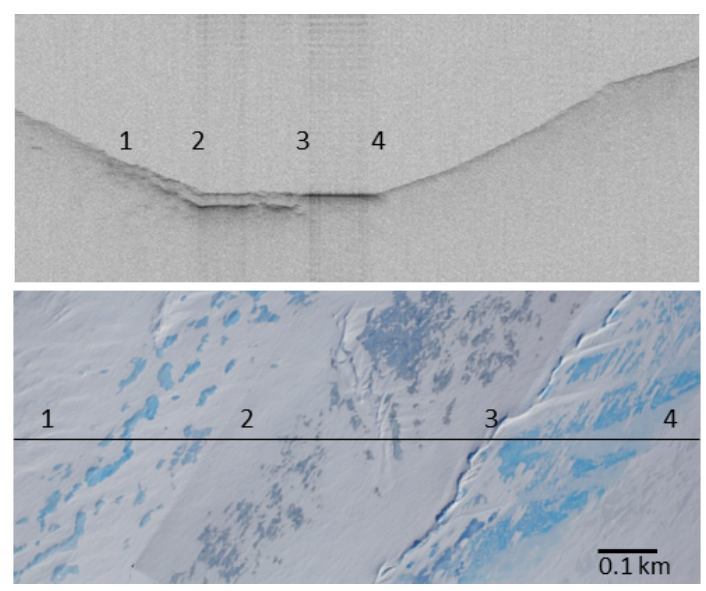

Figure 6. Snow Radar echogram (top) with DMS image of GrIS snow surface (bottom) taken on 2 May 2011 for a buried lake in northern Greenland $(\sim 100 \mathrm{~km}$ inland from the terminus of $79 \mathrm{~N}$ Glacier) showing from location 1 to 2 the turquoise blue refrozen lake, from 2 to 3 the darker blue retained water, a pressure ridge at 3 , and from 3 to 4 surface melt caused by radiative heating at the surface of the refrozen lake edge.

bond absorption feature near $600 \mathrm{~nm}$ (Grenfell and Perovich, 1981; Warren, 1984). The hydrogen bonds in water cause a shift to lower energy, over that of ice, which can produce the darker blue color (Luck, 1980; Langford et al., 2001). Unfortunately the DMS data used here cannot directly quantify the spectral signature.

Figure 6 shows a radar echogram and DMS image of a lake detected on 2 May 2011, approximately $100 \mathrm{~km}$ inland from the terminus of $79 \mathrm{~N}$ Glacier in northern Greenland. Radar backscatter clearly shows melt on the surface (Fig. 6 between locations 3 and 4) likely driven by radiative heating. The rest of the frozen lake (Fig. 6 between locations 1 and 2) and buried lake (Fig. 6 between locations 2 and 3) has persistent accumulated snow insulating the ice underneath and preventing the onset of melt. Landsat ETM+ images during the peak of the 2011 melt season (Fig. 7) demonstrate that lake extent corresponds to regions in the radar echogram where melt was initiated (Fig. 7 between locations 3 and 4) and that the region of the buried lake (Fig. 7 between locations 2 and 3) maintained a floating ice cap into the melt season. MODIS LST data, the only temperature data available for this site and date, show a peak temperature of $-10.7^{\circ} \mathrm{C}$ during the 16:40 GMT overpass. The Snow Radar and DMS data were acquired at 16:09 GMT, when OIB overflew the site very close to the peak temperature and solar input. The MODIS LST, however, is rather low for the production of water observed in the echogram over this site, which is probably the result of the relatively coarse spatial resolution $(1 \mathrm{~km})$ of MODIS such that the very small patch of surface melt, or melt from a few centimeters below the surface, at the edge of the lake, was not resolved. The evolution of this particu- 
Table 1. Number of buried lakes detected in each year along with the number of lakes detected per km of flight lines below $2000 \mathrm{~m}$, the mean elevation and standard deviation of buried lake elevations and the percentage of buried lake below $1000 \mathrm{~m}$ in elevation. See Fig. 6 for spatial distribution.

\begin{tabular}{llllll}
\hline $\begin{array}{l}\text { Year } \\
\text { collected }\end{array}$ & $\begin{array}{l}\text { Buried lakes } \\
\text { detected }\end{array}$ & $\begin{array}{l}\text { Buried lakes per } 1000 \mathrm{~km} \text { of } \\
\text { flight lines below } 2000 \mathrm{~m}\end{array}$ & $\begin{array}{l}\text { Mean } \\
\text { elevation }(\mathrm{m})\end{array}$ & $\begin{array}{l}\text { SD } \\
\text { elevation }\end{array}$ & $\begin{array}{l}\text { \% of buried lakes } \\
\text { below } 1000 \mathrm{~m}\end{array}$ \\
\hline 2009 & 57 & 2.1 & 1268 & 290 & 14 \\
2010 & 85 & 2.2 & 1180 & 399 & 33 \\
2011 & 174 & 3.9 & 1415 & 295 & 10 \\
2012 & 127 & 3.1 & 1371 & 332 & 15 \\
\hline
\end{tabular}

lar buried lake into the melt season is concentrated melting around the perimeter of the lake while the deeper center of the lake remains insulated with a floating cap, likely increasing the probability it will persist throughout the next winter season barring some supra- or englacial drainage event. These data also indicate that the early onset of melt is spatially heterogeneous, primarily occurring at locations where darker ice is exposed, and that some of the first melt of the season is associated with exposed buried lakes.

\subsection{Depth distribution of buried lakes}

Figure 8 shows a histogram of the digitized water layer depths from every radar return over a buried lake. The average depth to the retained water during the April and May OIB flights from 2009 to 2012 is $1.88+0.16 \mathrm{~m}$ with a total range of $0.05+0.01$ to $9.43+0.85 \mathrm{~m}$ and a standard deviation of $1.30 \mathrm{~m}$. There is not a distinctive pattern in buried lake depths along the margins of the GrIS. Thirty-eight percent of radar returns delineated a snow layer above the lake ice, with an average snow layer thickness over the buried lakes of $0.65 \mathrm{~m}$ (range of 0.15 to $2.93 \mathrm{~m}$ ) and an average ice layer thickness below the snow of $1.40 \mathrm{~m}$ (range of 0.4 to $4.58 \mathrm{~m}$ ). Uncertainties associated with estimates of density stratigraphy across the GrIS, which is used to convert radar travel time to depth, likely cause a shallow bias in these depth measurements of on average $9 \%$ and up to $24 \%$.

\section{Discussion}

\subsection{Buried lakes and surface mass budget}

Though the water stored in buried lakes is spatially extensive, it represents only a very small amount of mass likely of little consequence to mass loss projections for Greenland. Assuming all the buried lakes detected in 2011, the year with the maximum number of lakes, were the size of the mean supraglacial lake detected by Selmes et al. (2011), with a large water depth of $10 \mathrm{~m}$, the volume of water retained in the lakes would amount to $\sim 1.5 \mathrm{Gt}$ of water over an area of $\sim 140 \mathrm{~km}^{2}$. For comparison it is estimated that the firn aquifer covering $\sim 70000 \mathrm{~km}^{2}$ of southeast Greenland holds $\sim 140 \mathrm{Gt}$ of water (Forster et al., 2013; Koenig et al.,
2014), while recent models put GrIS runoff at between 100 and $300 \mathrm{Gt}$ annually (Vernon et al., 2013). The importance of buried lakes does not, therefore, lie so much in mass-loss contributions; rather the spatial distribution of the retained water is locally important for the development of the hydrologic system and ice temperatures.

\subsection{Lake evolution and implications for the hydrologic cycle}

The buried lakes identified and mapped in this study represent a newly documented class, or subset, of supraglacial lake. We emplace their formation with the following conceptual model. Once formed, a supraglacial lake can (1) drain through the englacial or supraglacial hydrologic system at some time throughout the year, most often during the melt season; (2) refreeze completely during the winter season; or (3) partially freeze during the winter season, form lake ice, and retain water at depth, becoming a buried lake. Buried lakes can resurface in the following melt season or remain buried for multiple seasons before re-emerging at the surface. As shown in Fig. 7, many of the re-emerging lakes have a characteristic crescent or toroid shape and maintain a floating cap of ice into the melt season. The formation of buried lakes on the GrIS follows the natural wintertime evolution of lake-ice formation observed over Arctic lakes on land, with similar ice thicknesses ranging between 1 and $2 \mathrm{~m}$ (e.g., Surdu et al., 2014). GrIS buried-lake formation also parallels melt pond refreezing on sea ice, wherein trapped ponds are created and persist until complete refreezing is accomplished (Flocco et al., 2015). Satellite images of the summertime extent of the supraglacial lakes paired with the subsurface radar data shown here suggest that at elevations above $1000 \mathrm{~m}$ all three types of supraglacial lakes coexist in the same region, all experiencing the same meteorological forcings. How and which supraglacial lakes become buried lakes is still unanswered, but a discussion of possible formation mechanisms and evolution is warranted.

The initial formation of a buried lake is likely dependent on two factors: (1) the degree of connectivity of the lake to the supra- and englacial hydrologic system responsible for the transport of water out of the lake and (2) the water volume stored in the lake at the end of the melt season, particularly 


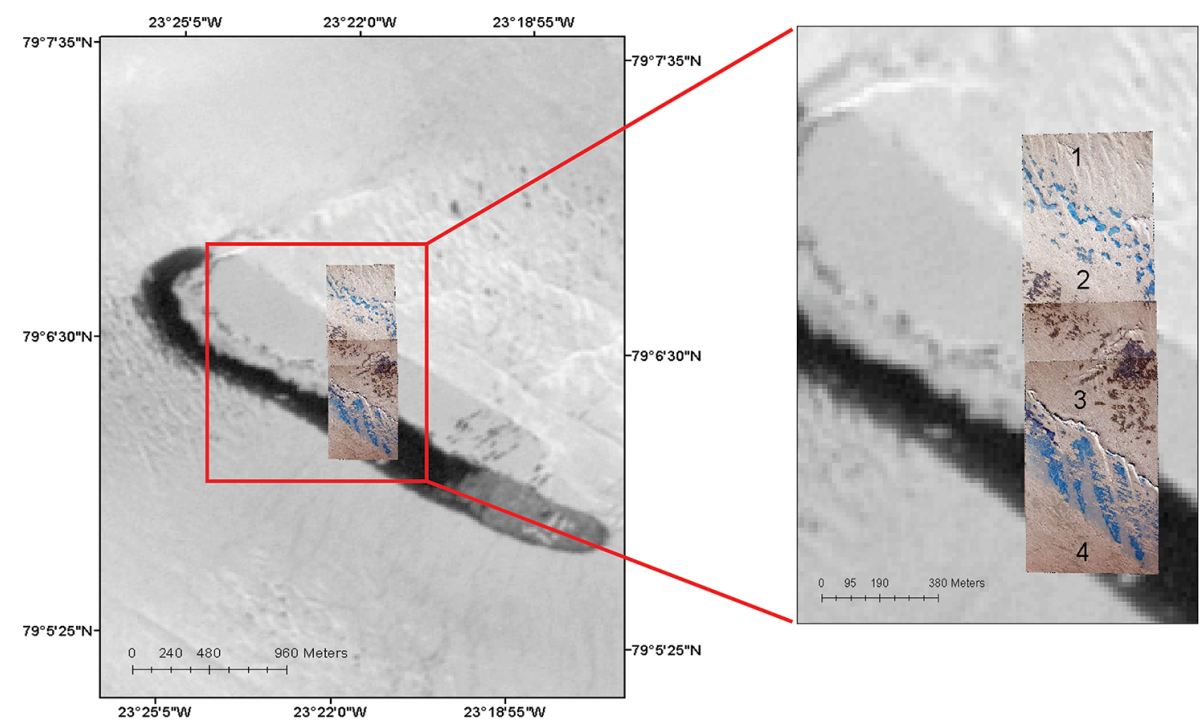

Figure 7. Image comparison of 2 May 2011 DMS image for the buried lake in Fig. 6 superimposed over a Landsat ETM+ image acquired on 19 July 2011, well into the melt season, when a supraglacial lake had formed. Expanded images are of the same location over the section of the lake where the early season radar data showed initial surface melt. The lake extent correlates with the early season melt area (between locations 3 and 4) and the area of stored water maintained a floating ice cap into the melt season (between locations 2 and 3 ).

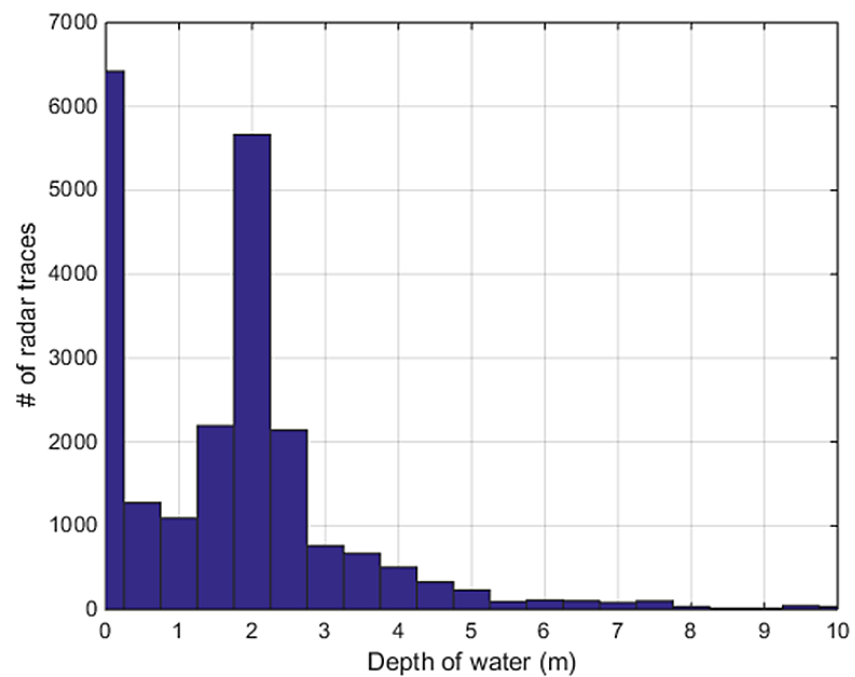

Figure 8. Histogram showing the depth of the water surface from every radar return over a buried lake from 2009 to 2012. Error estimates on the depth are on average $9 \%$ shallower due to uncertainties associated with the stratigraphy of density across the GrIS, which is used to convert radar travel time to depth.

the depth, which determines the energy balance required to freeze. Without further research and modeling it is unclear if either connectivity or depth is the more predominate factor in predicting buried-lake formation, but, with increasing melt extent across the GrIS (Mote et al., 2007; Nghiem et al., 2012; Hall et al., 2013), both may increase over time.
When a buried lake reaches the surface, and thaws, it will initially contain a larger amount of water in the lake basin than a neighboring drained basin at the start of the melt season. As the season progresses, less meltwater will be needed to fill the already partially filled basin. A more efficient filling of the lake basin would lead to more efficient overtopping and surface overflow, eventually leading to the development of supraglacial channels. Buried lakes tend to be prevalent at elevations coincident with the occurrence of lakes associated with more than one outflow channel (Lampkin et al., 2013). It is, therefore, possible that buried lakes, over time, promote supraglacial channel development leading to a more connected lake basin and diminishing the chances of a buried lake forming in subsequent seasons. More research is needed, but if this scenario is true, a buried lake may be a transient process in the development of a more efficient hydrologic system.

The retained water in buried lakes will also warm ice locally at the surface of the ice sheet as measured and modeled by Humphreys et al. (2012) and Kuipers Munneke et al. (2014). If the buried-lake water infiltrates cracks at the base of the lake, it is capable of delivering meltwater, and its associated latent heating, deeper into the ice sheet. The resultant heating and softening of the ice could affect iceflow dynamics, especially if concentrations of buried lakes are located at lateral margins of outlet glaciers. The rise in ice temperatures around conduits would also make it easier to activate the conduit in the spring/summer, supporting the hypothesis that buried lakes are part of the evolutionary cycle towards a more efficient drainage system. Considering this mechanism, buried lakes provide a possible water source 
for the peaks in stream discharge observed by Rennermalm et al. (2013) when no surface melt was present. Buried lakes represent a mechanism to extend surface meltwater infiltration deeper into the GrIS at any time during the year.

\section{Conclusions}

Buried supraglacial lakes are extensively distributed around the margins of the GrIS. A few previous studies suggested that water remained in the supraglacial lakes late into the winter season; however, these data are the first to confirm and map extensively the distribution of the retained water. Though the water retained in buried supraglacial lakes is insignificant compared to total mass loss, it has important implications for the local temperature profile, development of the englacial hydrologic network and ice dynamics. This research presents a new understanding of meltwater routing through and within the GrIS and emphasizes the need to better understand the hydrologic pathways through which meltwater drains toward the ocean.

Acknowledgements. The authors thank L. Brucker and T. Neumann for their insightful discussions. This work was supported by NASA's New Investigator and Cryospheric Sciences Programs. Data collection and instrument development were made possible by The University of Kansas' Center for Remote Sensing of Ice Sheets (CReSIS), supported by the National Science Foundation and Operation IceBridge. S. E. Moutsafa supported by NASA's Earth and Space Science Fellowship Program grant NNX12AN98H.

Edited by: R. Bingham

\section{References}

Angelen, J. H., Broeke, M. R., Wouters, B., and Lenaerts, J.: Contemporary (1960-2012) evolution of the climate and surface mass balance of the greenland ice sheet, Surv. Geophys., 35, 1155-1174, doi:10.1007/s10712-013-9261-z, 2014.

Bartholomew, I., Nienow, P., Sole, A., Mair, D., Cowton, T., Palmer, S., and Wadham, J.: Supraglacial forcing of subglacial drainage in the ablation zone of the Greenland ice sheet, Geophys. Res. Lett., 38, L08502, doi:10.1029/2011GL047063, 2011.

Benson, C. S.: Stratigraphic studies in the snow and firn of the Greenland ice sheet, No. RR70, COLD REGIONS RESEARCH AND ENGINEERING LAB HANOVER NH, 1962.

Box, J. E. and Ski, K.: Remote sounding of Greenland supraglacial melt lakes: implications for subglacial hydraulics, J. Glaciol., 53, 257-265, doi:10.3189/172756507782202883, 2007.

Box, J. E., Fettweis, X., Stroeve, J. C., Tedesco, M., Hall, D. K., and Steffen, K.: Greenland ice sheet albedo feedback: thermodynamics and atmospheric drivers, The Cryosphere, 6, 821-839, doi:10.5194/tc-6-821-2012, 2012.

Catania, G. A., Neumann, T. A., and Price, S. F.: Characterizing englacial drainage in the ablation zone of the Greenland ice sheet,
J. Glaciol., 54, 567-578, doi:10.3189/002214308786570854, 2008.

Comiso, J. C.: Warming Trends in the Arctic from Clear Sky Satellite Observations, J. Clim., 16, 3498-3510, doi:10.1175/15200442, 2003.

Das, S. B., Joughin, I., Behn, M. D., Howat, I. M., King, M. A., Lizarralde, D., and Bhatia, M. P.: Fracture propagation to the base of the Greenland Ice Sheet during supraglacial lake drainage, Science, 320, 778-781, doi:10.1126/science.1153360, 2008.

Dominguez, R.: IceBridge DMS L1B Geolocated and Orthorectified Images, Boulder, Colorado USA: NASA National Snow and Ice Data Center Distributed Active Archive Center, available at: http://dx.doi.org/10.5067/OZ6VNOPMPRJ0, 2010 (updated 2014).

Dowdeswell, J. A. and Evans, S.: Investigations of the form and flow of ice sheets and glaciers using radio-echo sounding, Rep. Prog. Phys., 67, 1821-1861, doi:10.1088/0034-4885/67/10/R03, 2004.

Echelmeyer, K., Clarke, T. S., and Harrison, W. D.: Surficial glaciology of Jakobshavn Isbræ, West Greenland 1. Surfacemorphology, J. Glaciol., 37, 368-382, 1991.

Enderlin, E. M., Howat, I. M., Jeong, S., Noh, M. J., van Angelen, J. H., and van den Broeke, M. R.: An improved mass budget for the Greenland ice sheet, Geophys. Res. Lett., 41, 866-872, doi:10.1002/2013GL059010, 2014.

Flocco, D., Feltham D. L., Bailey, E., and Schroeder, D.: The refreezing of melt ponds on Arctic sea ice, J. Geophys. Res. Oceans, 120, 647-659, doi:10.1002/2014JC010140, 2015.

Forster, R. R., Box, J. E., van den Broeke, M. R., Miège, C., Burgess, E. W., van Angelen, J. H., Lenaerts, J. T. M., Koenig, L. S., Paden, J., Lewis, C., Gogineni, S. P., Leuschen, C., and McConnell, J. R.: Extensive liquid meltwater storage in firn within the Greenland ice sheet, Nature Geosci., 7, 95-98, doi:10.1038/ngeo2043, 2013.

Grenfell, T. C. and Perovich, D. K.: Radiation absorption-coefficients of polycrystalline ice from 400$1400 \mathrm{~nm}$, J. Geophys. Res. Atmos., 86, 7447-7450, doi:10.1029/JC086iC08p07447, 1981.

Hall, D. K., Box, J. E., Casey, K. A., Hook, S. J., Shuman, C. A., and Steffen, K.: Comparison of satellite-derived and in-situ observations of ice and snow surface temperatures over Greenland, Remote Sens. Environ., 112, 3739-3749, doi:10.1016/j.rse.2008.05.007, 2008

Hall, D. K., Comiso, J. C., DiGirolamo, N. E., Shuman, C. A., Box, J. E., and Koenig, L. S.: Variability in the surface temperature and melt extent of the greenland ice sheet from MODIS, Geophys. Res. Lett., 40, 2114-2120, doi:10.1002/grl.50240, 2013.

Hanna, E., Fettweis, X., Mernild, S. H., Cappelen, J., Ribergaard, M. H., Shuman, C. A., Steffen, K., Wood, L., and Mote, T. L.: Atmospheric and oceanic climate forcing of the exceptional Greenland ice sheet surface melt in summer 2012, Int. J. Climatol., 34, 1022-1037, doi:10.1002/joc.3743, 2014.

Harper, J., Humphrey, N., Pfeffer, W. T., Brown, J., and Fettweis, X.: Greenland ice-sheet contribution to sea-level rise buffered by meltwater storage in firn, Nature, 491, 240-243, doi:10.1038/nature11566, 2012.

Hoffman, M. J., Catania, G. A., Neumann, T. A., Andrews, L. C., and Rumrill, J. A.: Links between acceleration, melting, and 
supraglacial lake drainage of the western Greenland Ice Sheet, J. Geophys. Res. Surf., 116, F04035, doi:10.1029/2010JF001934, 2011.

Howat, I. M., de la Pena, S., van Angelen, J. H., Lenaerts, J. T. M., and van den Broeke, M. R.: Expansion of meltwater lakes on the Greenland Ice Sheet, The Cryosphere, 7, 201-204, doi:10.5194/tc-7-201-2013, 2013.

Humphrey, N. F., Harper, J. T., and Pfeffer, W. T.: Thermal tracking of meltwater retention in Greenland's accumulation area, J. Geophys. Res., 117, F01010, doi:10.1029/2011JF002083, 2012.

Joughin, I., Das, S. B., King, M. A., Smith, B. E., Howat, I. M., and Moon, T.: Seasonal speedup along the western flank of the Greenland Ice Sheet, Science, 320, 781-783, doi:10.1126/science.1153288, 2008.

Khan, S. A., Kjaer, K. H., Bevis, M., Bamber, J. L., Wahr, J., Kjeldsen, K. K., Bjork, A. A., Korsgaard, N. J., Stearns, L. A., van den Broeke, M. R., Liu, L., Larsen, N. K., and Muresan, I. S.: Sustained mass loss of the northeast greenland ice sheet triggered by regional warming, Nature Clim. Change, 4, 292-299, doi:10.1038/nclimate2161, 2014.

Koenig, L. S. and Hall, D. K.: Comparison of satellite, thermochron and air temperatures at Summit, Greenland, during the winter of 2008/09, J. Glaciol., 56, 735-741, 2010.

Koenig, L. S., Miège, C., Forster, R. R., and Brucker, L.: Initial in situ measurements of perennial meltwater storage in the Greenland firn aquifer, Geophys. Res. Lett., 41, 81-85, doi:10.1002/2013GL058083, 2014.

Kuipers Munneke, P., M. Ligtenberg, S. R., van den Broeke, M. R., van Angelen, J. H., and Forster, R. R.: Explaining the presence of perennial liquid water bodies in the firn of the Greenland Ice Sheet, Geophys. Res. Lett., 41, 476-483, doi:10.1002/2013GL058389, 2014.

Lampkin, D. J.: Supraglacial lake spatial structure in western Greenland during the 2007 ablation season, J. Geophys. Res., 116, F04001, doi:10.1029/2010JF001725, 2011.

Lampkin, D. J. and VanderBerg, J.: Supraglacial melt channel networks in the Jakobshavn Isbræ region during the 2007 melt season, Hydrol. Process., 28, 6038-6053 doi:10.1002/hyp.10085, 2013.

Langford, V. S., McKinley, A. J., and Quickenden, T. I.: Temperature dependence of the visible-near-infrared absorption spectrum of liquid water, J. Phys. Chem. A, 105, 8916-8921, doi:10.1021/jp010093m, 2001.

Leuschen, C.: IceBridge Snow Radar L1B Geolocated Radar Echo Strength Profiles, Boulder, Colorado, NASA DAAC at the National Snow and Ice Data Center, doi:10.5067/05LF3JANL51I, 2014.

Luck, W. A. P.: A Model of Hydrogen-Bonded Liquids, Angewandte Chemie International Edition in English, 19, 28-41, 1980.

McMillan, M., Nienow, P., Shepherd, A., Benham, T., and Sole, A.: Seasonal evolution of supra-glacial lakes on the Greenland Ice Sheet, Earth Planet. Sci. Lett., 262, 484-492, doi:10.1016/j.epsl.2007.08.002, 2007.

Mote, T. L.: Greenland surface melt trends 1973-2007: Evidence of a large increase in 2007, Geophys. Res. Lett., 34, L22507, doi:10.1029/2007g1031976, 2007.

Nghiem, S. V., Hall, D. K., Mote, T. L., Tedesco, M., Albert, M. R., Keegan, K., Shuman, C. A., DiGirolamo, N. E., and Neumann,
G.: The extreme melt across the Greenland ice sheet in 2012, Geophys. Res. Lett., 39, L20502, doi:10.1029/2012GL053611, 2012.

Ohmura, A., Steffen, K., Blatter, H., Greuell, W., Rotach, M., Konzelmann, T., Laternser, M., Ouchi, A., and Steiger, D.: Energy and mass balance during the melt season at the equilibrium line altitude, Paakitsoq, Greenland ice sheet. Progress Report No. 1, Eidgenoss. Tech. Hochschule, Zurich, Department of Geography, 1991.

Palmer, S., Shepherd, A., Nienow, P., and Joughin, I.: Seasonal speedup of the Greenland Ice Sheet linked to routing of surface water, Earth Planet. Sci. Lett., 302, 423-428, doi:10.1016/j.eps1.2010.12.037, 2011.

Panzer, B., Gomez-Garcia, D., Leuschen, C., Paden, J., RodriguezMorales, F., Patel, A., Markus, T., Holt, B., and Gogineni, P.: An ultra-wideband, microwave radar for measuring snow thickness on sea ice and mapping near-surface internal layers in polar firn, J. Glaciol., 59, 244-254, doi:10.3189/2013JoG12J128, 2013.

Rennermalm, A. K., Smith, L. C., Chu, V. W., Box, J. E., Forster, R. R., Van den Broeke, M. R., Van As, D., and Moustafa, S. E.: Evidence of meltwater retention within the Greenland ice sheet, The Cryosphere., 7, 1433-1445, doi:10.5194/tc-7-1433-2013, 2013.

Rodriguez-Morales, F., Gogineni, S., Leuschen, C. J., Paden, J. D., Li, J., Lewis, C. C., Panzer, B., Alvestegui, D. G.-G., Patel, A., Byers, K., Crowe, R., Player, K., Hale, R. D., Arnold, E. J., Smith, L., Gifford, C. M., Braaten, D., and Panton, C.: Advanced Multifrequency Radar Instrumentation for Polar Research, IEEE T. Geosci. Remote Sens., 52, 2824-2842, doi:10.1109/TGRS.2013.2266415, 2014.

Selmes, N., Murray, T., and James, T. D.: Fast draining lakes on the Greenland Ice Sheet, Geophys. Res. Lett., 38, L15501, doi:10.1029/2011GL047872, 2011.

Shepherd, A., Ivins, E. R., Geruo, A., Barletta, V. R., Bentley, M. J., Bettadpur, S., Briggs, K. H., Bromwich, D. H., Forsberg, R., Galin, N., Horwath, M., Jacobs, S., Joughin, I., King, M. A., Lenaerts, J. T. M., Li, J., Ligtenberg, S. R. M., Luckman, A., Luthcke, S. B., McMillan, M., Meister, R., Milne, G., Mouginot, J., Muir, A., Nicolas, J. P., Paden, J., Payne, A. J., Pritchard, H., Rignot, E., Rott, H., Sørensen, L. S., Scambos, T. A., Scheuchl, B., Schrama, E. J. O., Smith, B., Sundal, A. V., van Angelen, J. H., van de Berg, W. J., van den Broeke, M. R., Vaughan, D. G., Velicogna, I., Wahr, J., Whitehouse, P. L., Wingham, D. J., Yi, D., Young, D., and Zwally, H. J.: A reconciled estimate of ice-sheet mass balance., Science, 338, 1183-1189, doi:10.1126/science.1228102, 2012.

Sneed, W. A. and Hamilton, G. S.: Validation of a method for determining the depth of glacial melt ponds using satellite imagery, Ann. Glaciol., 52, 15-22, 2011.

Sundal, A. V., Shepherd, A., Nienow, P., Hanna, E., Palmer, S., and Huybrechts, P.: Evolution of supra-glacial lakes across the Greenland Ice Sheet, Remote Sens. Environ., 113, 2164-2171, doi:10.1016/j.rse.2009.05.018, 2009.

Sundal, A. V., Shepherd, A., Nienow, P., Hanna, E., Palmer, S., and Huybrechts, P.: Melt-induced speed-up of Greenland ice sheet offset by efficient subglacial drainage, Nature, 469, 522-583, doi:10.1038/nature09740, 2011.

Surdu, C. M., Duguay, C. R., Brown, L. C., and Fernandez Preto, D.: Response of ice cover on shallow lakes of the North Slope of Alaska to contemporary climate conditions (1950-2011): 
radar remote-sensing and numerical modeling data analysis, The Cryosphere, 8, 167-180, doi:10.5194/tc-8-167-2014, 2014.

Tedesco, M. and Steiner, N.: In-situ multispectral and bathymetric measurements over a supraglacial lake in western Greenland using a remotely controlled watercraft, The Cryosphere, 5, 445452, doi:10.5194/tc-5-445-2011, 2011.

Tedesco, M., Fettweis, X., Van den Broeke, M., Van de Wal, R., Smeets, C., Van de Berg, W., Serreze, M., and Box, J.: The role of albedo and accumulation in the 2010 melting record in Greenland, Environ. Res. Lett., 014005, doi:10.1088/17489326/6/1/014005, 2011.

Tedstone, A. J., Nienow, P. W., Sole, A. J., Mair, D. W. F., Cowton, T. R., Bartholomew, I. D., and King, M. A.: Greenland ice sheet motion insensitive to exceptional meltwater forcing, P. Natl. Acad. Sci. USA, 110, 19719-19724, doi:10.1073/pnas.1315843110, 2013.

Ulaby, F. T., Moore, R. K., and Fung, A. K.: Microwave Remote Sensing: Active and Passive, Vol. 2. Reading, Mass: AddisonWesley Pub. Co., Advanced Book Program/World Science Division, 1981.

van den Broeke, M., Bamber, J., Ettema, J., Rignot, E., Schrama, E., van de Berg, W. J., van Meijgaard, E., Velicogna, I., and Wouters, B.: Partitioning Recent Greenland Mass Loss, Science, 326, 984 986, doi:10.1126/science.1178176, 2009.
Vernon, C. L., Bamber, J. L., Box, J. E., van den Broeke, M. R., Fettweis, X., Hanna, E., and Huybrechts, P.: Surface mass balance model intercomparison for the Greenland ice sheet, The Cryosphere, 7, 599-614, doi:10.5194/tc-7-599-2013, 2013.

Wan, Z. M., Zhang, Y. L., Zhang, Q. C., and Li, Z. L.: Validation of the land-surface temperature products retrieved from Terra Moderate Resolution Imaging Spectroradiometer data, Remote Sens. Environ., 83, 163-180, 2002.

Warren, S. G.: Optical-constants of ice from the ultraviolet to the microwave, Appl. Opt., 23, 1206-1225, 1984.

Wiesmann, A. and Matzler, C.: Microwave emission model of layered snowpacks, Remote Sens. Environ., 70, 307-316, doi:10.1016/S0034-4257(99)00046-2, 1999.

Zwally, H. J., Abdalati, W., Herring, T., Larson, K., Saba, J., and Steffen, K.: Surface melt-induced acceleration of Greenland ice-sheet flow, Science, 297, 218-222, doi:10.1126/science.1072708, 2002. 